\title{
$\begin{array}{r}\text { WAGENINGEN } \\ \hline\end{array}$
}

The Missing Link: Sustainable Mobility for Sustainable Cities and

\author{
Communities
}

Tan, W. G. Z.

This is a "Post-Print" accepted manuscript.

This version is distributed under a non-commercial no derivatives Creative Commons (c) (1) @ @ ( 9 (CC-BY-NC-ND) user license, which permits use, distribution, and reproduction in any medium, provided the original work is properly cited and not used for commercial purposes. Further, the restriction applies that if you remix, transform, or build upon the material, you may not distribute the modified material.

Please cite this publication as follows:

Tan, W. G. Z. (2018). The Missing Link: Sustainable Mobility for Sustainable Cities and Communities. In R. Holzhacker, \& D. Agussalim (editors), Sustainable Development Goals in Southeast Asia and ASEAN : National and Regional Approaches (blz. 210-231). (Political Ecology in the Asia Pacific Region; Vol. 1). Brill. https://doi.org/10.1163/9789004391949_011

You can download the published version at:

https://doi.org/10.1163/9789004391949 011 


\title{
Chapter 10
}

\section{The Missing Link: Sustainable Mobility for Sustainable cities and communities}

Wendy Tan, Western Norway University of Applied Sciences, Norway and Wageningen University and Research, the Netherlands

\begin{abstract}
Within the Sustainable Development Goals adopted by the United Nations in 2015, Goal 11 promotes sustainable cities and communities. To achieve that aim, this SDG must address the vicious cycle of rapid urbanization and increased motorization intertwined with the social, economic, and political context unique to every city. This chapter argues that SDG 11 lacks specificity and feasibility for implementation. Considering the paradigm shift from conventional transport planning to a sustainable mobility approach in the context of Southeast Asia, this chapter highlights the missing links in SDG 11 through the lens of sustainable mobility, mobility inequalities, and transport related social exclusion. Comparing active mobility projects and land use transportation integration policies and implementation in Singapore and Jakarta reveals how goals are subjected to governance structures, political will, and public acceptance. The policy coherence and governance in Singapore contribute to its effective and refined policies, while Jakarta has the advantage of civil society involvement. Analysing the distance, time, and cost required to conduct a similar, fictitious journey in each city, the contextual limitations contributing to mobility inequalities and exclusions are presented. Reflecting on potential roles for governments, market parties, and civil society, the chapter concludes with a discussion on innovations required for systemic change to achieve sustainable cities and communities.
\end{abstract}




\section{L1 Introduction}

As Southeast Asian cities experience explosive economic growth and urbanization, various spatial claims and conflicts arise. One particular conflict is the fundamental mismatch between land use and transportation polices representative of cities and metropolitan regions in Southeast Asia. Here, the growing population and their increased car usage due to improving economic circumstances have led to a path of "automobile dependence" (Barter, 2004) with increasing mobility demand from all socio-economic levels, coupled with the urge to emulate misconstrued "Western" or “American” urban development ideals (Shatkin, 2008; World Bank, 2015). These cities have uncritically facilitated development and mobility in the form of modern skyscrapers and soaring freeways, thereby producing the familiar images of traffic congestion and haphazard urban development (Buijs, Tan, \& Tunas, 2010).

Mobility, understood as the ability to move oneself, is a fundamental human right (UN, 1948). However, the impacts of fulfilling this right often clash with sustainable development ideals. For example, Bangkok, Thailand and Jakarta, Indonesia rank as the second and third most congested cities in the world (INRIX, 2017; TomTom, 2017). In addition to the negative effects of increased fossil fuel consumption leading to emissions and toxic fumes, and diminishing road safety (Bakker et al., 2017), traffic congestion also means that significant numbers of people spend a disproportionate amount of their time in relation to their income opportunities waiting in traffic trying to get to work, to school or to other social needs. This has serious consequences for sustainable development in terms of increasing social inequalities and exclusion in these cities (UN Habitat, 2013). When certain parts of a city are gridlocked, basic access to healthcare, education, and facilities can no longer be guaranteed. This contributes to the growing discussions on transportrelated social exclusion (TRSE) within the fields of land use and transport planning (Kenyon, Lyons, \& Rafferty, 2002; Lucas, van Wee, \& Maat, 2016; Scheurer, Curtis, \& McLeod, 2017).

This inherent conflict between balancing social, economic, and environmental objectives makes the discussion of sustainable mobility both complicated and complex. This complexity is especially visible in the developmental state narrative in which the majority of Association of Southeast Asian Nations (ASEAN) member states find themselves, where the urgency and speed of economic growth sometimes overshadow environmental and social concerns (Johnson, 1999). It is therefore relevant to consider the complex role that land use and transportation planning have in achieving sustainable development futures. ASEAN members are currently at various stages in their pursuit of 
sustainable urban development, having advanced significantly since the ASEAN Vision 2025 was agreed upon (UN ESCAP, 2017). However, substantial structural challenges remain, notably those of access to healthcare and education, and the gap between income classes despite a growing 'middle' class (Development Initiatives, 2017).

Contrasting this initial progress with the 17 Sustainable Development Goals (SDGs) agreed by the United Nations in the 2030 Agenda for Sustainable Development (UN, 2015), one observes that there is much room for improvement. The SDGs, as measured by a variety of indicators, are meant to guide national policies to achieve an inclusive, sustainable, and prosperous future. The goals themselves, however, were formulated rather vaguely to achieve broad consensus and adoption by various nation states and across various levels and scales. Amongst the various goals and indicators, only SDG 11 (UN, 2015, 2017) carries an explicit reference to transport and sustainable mobility in terms of "safe, affordable, accessible and sustainable transport systems for all". However, the nonspecificity of its indicators (i.e. measured as the "proportion of the population that has convenient access to public transport", Indicator 11.2.1) might prove challenging for implementation in practice.

To understand how SDG 11 (Sustainable cities and communities) relates to sustainable mobility in the Southeast Asian context, this chapter will discuss the Goal through the lens of transportation and mobility planning to highlight the missing links and dilemmas. First, the fundamental concepts of sustainable mobility, its common strategies and its relation to social inequalities are discussed. Then, SDG 11 and its indicators are analysed along with the four elements of sustainable mobility. Next, by comparing active mobility projects and land use transportation integration policies in the cases of Singapore and Jakarta in relation to a similar fictitious journey in both cities, the policy context and implementation challenges of achieving SDG 11 are highlighted. The discussion ends with a reflection on potential roles for governments, markets, and civil society to reduce mobility inequality and exclusions.

\section{L1 Theory}

Transport has been termed the "maker and breaker of cities" (Clark, 1958). In a context of rapid urban population growth, cities are bursting at the seams to accommodate residents and retain an acceptable quality of life. Congestion, pollution, and excessive commuting times are just some of 
the most direct and observable impacts experienced by those living in cities. Within the ASEAN region, population increases and unsustainable development strategies focused on growth and expansion have already led to measurable degradation in water and air quality, and displacement of local populace and businesses (Firman \& Dharmapatni, 1994). Achieving a sustainable future therefore requires a better understanding of Southeast Asian city-regions through the lens of sustainable mobility instead of the traditional transport planning approaches (Buijs et al., 2010). In this section, the differences between sustainable mobility and conventional transportation planning are discussed and two commonly used strategies explained. The social aspects of transport planning and sustainable mobility are then reflected upon from the perspectives of transport-related social exclusion and the rights-based approach to mobility.

\section{L2 Sustainable Mobility vs. Transportation Planning}

There has been a fundamental shift within the field of mobility and transportation planning in the last decades (Hull, 2008). No longer is the "predict and provide" narrative preached but rather a "predict and prevent" or "people and places" approach is adopted (Owens, 1995; see also Bakker et al., 2017; Banister, 2008). The technical-rationality approach to transportation planning, in which the emphasis is on increasing infrastructure efficiency to achieve a pre-determined goal in a transportation system, is outdated (Wilson, 2001). The vicious cycle of building more infrastructure (predominantly highways) for private car use and expanding traffic capacity has been proven to lead to more congestion, the need for more roads, and more private car use - with all the negative impacts that this entails (Ladd, 2012).

This has led to a paradigm shift in the field of transportation planning and its key debates, captured in the seminal text by Banister (2008, p. 73):

It has often been said that transport planning is at a crisis point and that it underestimates the key challenges facing urban planners .... Local public transport, cycle and walking have become less attractive, and this in turn has resulted in the greater use of the car. Car dependence and the increased decentralisation of cities are difficult processes to reverse this is the transport-led future. Sustainable mobility provides an alternative paradigm within which to investigate the complexity of cities, and to strengthen the links between land use and transport.

With this fundamental change, the new focus in transport planning is to reduce travel in terms of trips and trip lengths, to encourage travellers to choose more sustainable modes of transport (that is, 
a modal shift from private car use to walking, cycling, or public transportation), and to increase efficiency of the transportation system. However, this can only be achieved if there is public and political acceptance. To make these changes palatable or appealing, individuals will have to be shown the possible gains and the concrete possibility of implementing sustainable mobility — and the risks of maintaining the status quo (Banister, 2008, 2011).

To attain sustainable mobility, a combination of the following four key elements must be present in any transport policy seeking modal shift (Banister, 2008):

1) Adapting and investing in technology to increase efficiency (e.g., alternative fuels or information systems);

2) Reflecting the real costs and externalities of transport (e.g., road pricing or additional fuel tax);

3) Integrating land use with transport (e.g., proximity measures, compact developments);

4) Behavioural change and acceptance (e.g., targeted personal information, campaigns promoting active modes such as walking or cycling).

\section{L2 Active Modes and Land Use Transport Integration}

Within sustainable mobility discussions, two popular strategies which combine the above elements and which are adopted by cities are (1) active mobility policies to promote cycling and/or walking, and (2) land use transport integration (LUTI) in the form of transit-oriented development (Kenworthy, 2007).

The first seeks to change behaviours by providing incentives for modal shift towards more non-car based transportation such as walking and cycling, eventually encouraging more public transportation usage. The underlying motivations have always been possible emission reductions from these modes, as well as the potential health and well-being advantages (P茾her \& Dijkstra, 2011). For example, for longer journeys, if there were more connected and continuous cycle and walking paths, then an individual would be able to conduct their first-mile and last-mile journeys by those modes instead of having to rely on a private car to reach other transit options, or having to drive the entire trip. For shorter, daily trips for groceries or errands, for example, the strategy would then focus on reducing the time, cost or effort of walking or cycling in comparison to taking the car.

The second strategy combines compact, high-density developments around public transportation nodes to encourage transit use and increase the efficiency of current land use and transportation 
systems (Loo \& du Verle, 2016). The foundation of this concept is found in the land use-transport feedback loop which contends that there is a mutual and cyclical relationship between land use patterns and changes in the transportation systems (Wegener \& Fürst, 1999). Transit-oriented development (TOD) refers to mixed-used residential and commercial development that is oriented towards and in close proximity to a multi-modal transportation node (Mees, 2014; Tan, Bertolini, \& Janssen-Jansen, 2014). These compact and dense settlements, where individuals can walk to take public transportation or can engage in retail, leisure or work in the direct vicinity through walking instead of driving long distances, are deemed to be sustainable for the environment but also to encourage economic and social activities.

\section{L2 Mobility Inequalities and Exclusion}

Discussing sustainable mobility purely from an infrastructural or functional perspective, however, does not present a full picture. Its predominant contribution is in the alleviation of inequalities and social exclusion. This was a fundamental flaw in traditional transport planning, which was more preoccupied with the system and capacity improvements then with the individuals using the system, and their differentiated needs. The social aspects of mobility can be discussed through two lenses: transport related social exclusion; and the rights-based approach to mobility.

TRSE focuses on how lack of access to transportation limits the participation of individuals in society. This is measured by access to employment, education, healthcare, and services (Preston \& Rajé, 2007). Social exclusion, including that caused by lack of transportation access, is not unique to Southeast Asia. What is important is how pervasive and influential it can be in contributing to poverty and in preventing the social mobility implied by better education and employment opportunities. Access to basic services such as hospitals or schools and uneven spatial distribution of key facilities are made worse by the excessive congestion common to the region (Rama, Béteille, Li, Mitra, \& Newman, 2015).

The rights-based approach is concerned with who might be excluded and marginalized due to their income levels or even ethnicity determining their spatial location, usually at the outskirts of cities where residences are cheaper (Coggin, 2017). This is compounded by the fact that most of these individuals, usually women or elderly already spatially isolated from main commercial activities, are less likely to be able to afford a private car to get to those activities (Thynell, 2017). As such, the lack of access to transportation systems leads to compounding social and economic inequalities. 
For example, if a disproportionate amount of an individual's working income is required to simply get to and from the work location, this restricts the ability to pay for food, healthcare, or education.

When discussing transport and mobility issues, it is thus imperative not to ignore the social aspects of sustainability and focus only on the functional. For sustainable cities and communities, "the accessibility planning (in its broadest sense) of public transport which is necessary to meet the travel needs of socially excluded people must be highly integrated with socially responsible land use, housing, health, education and welfare policies and programmes" (Lucas, 2012, p. 112).

\section{L1 Method}

To understand how sustainable mobility can help in achieving sustainable cities and communities in Southeast Asia, this chapter first analyses SDG 11 and its indicators according to the four elements of sustainable mobility. As described above, these four elements are: adapting and investing in technology to increase efficiency; reflecting the real costs and externalities of transport; integrating land use with transport; and behavioural change and acceptance. To investigate how the combinations of these four elements could be implemented in practice, two cities in Southeast Asia are then compared for their recent sustainable mobility policies in active mobility projects (cycling and walking) and LUTI policies, illustrating the relationship between sustainable mobility and sustainable cities and communities. Comparing the city of Singapore and the city of Jakarta, the units of analysis are recent projects and policies showing the context for implementation. Here, Singapore is chosen as an exemplary case due to its constant innovations for sustainable mobility and transportation, such as the electronic road pricing system. Jakarta, the second most congested city in the world, is a more representative case for the sustainable mobility capacity of the other cities in the region. Each case will be described in general and in the context of its achievements in sustainable mobility in the last decade. The specific policies or projects of each city will be listed and analysed along with the four elements of sustainable mobility and how SDG 11 might or might not apply.

The recent projects and policies are selected based on the following criteria:

- Status as the latest iteration of national or local plans and policies or projects within the last decade; 
- Clear objectives to encourage modal shift away from private car use through either active mobility (cycling and walking) or LUTI (TOD) policies, and/or other elements of sustainable mobility;

- Clarity in governance structures and implementation strategy embedded in existing formal and informal institutions (that is, priority given to formalized strategies and plans).

To provide a complete context for comparison, a fictitious journey from a commuter town or suburb to the economic centre of each city will be constructed for the modes of private car, urban rail, bus and walking. Each mode will be measured in terms of the distance, time, and cost involved in making such a journey: this is to ensure some internal validity given that the socio-political contexts of the two cities are vastly different. Distance, time, and costs are the key factors that affect travel behaviour and mode choice (Annema, 2013). Assessing the comparison between the two cities in terms of these factors, and in light of the approach to projects and policies, the perspective of sustainable mobility in relation to mobility inequalities and exclusion is then discussed.

\section{L1 Findings}

\section{L2 Sustainable Development Goal 11}

Much like the Millennium Development Goals (MDG) which preceded them, transport is not a specific focus of the SDGs although it is implicitly present in various goals relating to health, energy, and equality. The most prominent SDG in which transport is mentioned is SDG 11 ("Make cities and human settlements inclusive, safe, resilient and sustainable") and specifically Target 11.2: "By 2030, provide access to safe, affordable, accessible and sustainable transport systems for all, improving road safety, notably by expanding public transport, with special attention to the needs of those in vulnerable situations, women, children, persons with disabilities and older persons" (UN, 2015; see also IAEG, 2016). The only other mention is found in SDG 9, Target 9.1. ${ }^{1}$ It is ironic that in a document that avoids the term "transport", so many of the indicators are focused on measuring the effects of transportation systems in the forms of outputs and emissions $\left(\mathrm{CO}_{2}\right.$ or particulate matter). This does not match up to the state-of-the-art in transport planning discourse, namely sustainable mobility.

\footnotetext{
${ }^{1}$ Target 9.1 reads: "Develop quality, reliable, sustainable and resilient infrastructure, including regional and trans-border infrastructure, to support economic development and human well-being, with a focus on affordable and equitable access for all”.
} 
Take SDG 11: Make cities and human settlements inclusive, safe, resilient and sustainable and its sub-goals for example;

Target 11.2 in itself ticks none of the elements of sustainable mobility directly, except for a general increase in the efficiency of the public transportation system. When looked at in the light of transport-related social exclusion and rights-based approaches, it does call for special attention for the vulnerable groups of elderly, women, children, and disabled. However, how this can be implemented is unaddressed; Target 11.2 is to be measured by Indicator 11.2.1 as the "proportion of population that has convenient access to public transport, by sex, age and persons with disabilities" (UN, 2015). This is simultaneously specific and vague. Having a large proportion of the population able to access public transport "conveniently" says nothing about their eventual adoption of that mode for their travels, whether public transport will become their primary day-to-day form of transport, or whether it will help increase their access to employment, education or healthcare. The spatial element is also neglected. Social and spatial inequalities are de facto conditions in Southeast Asian cities. If the proportion with increased and convenient access to public transportation grows, but mostly consists of those of a higher social or income level (e.g. opening of new stations or increased bus routes in wealthy areas) then this indicator does not contribute much to improving sustainable cities or communities.

Target 11.3 provides more hope as it names inclusiveness and capacity for participation of civil society as key factors. The target reads: "By 2030, enhance inclusive and sustainable urbanization and capacity for participatory, integrated and sustainable human settlement planning and management in all countries". The two indicators accompanying the target are: "11.3.1: Ratio of land consumption rate to population growth rate"; and "11.3.2: Proportion of cities with a direct participation structure of civil society in urban planning and management that operate regularly and democratically". This is echoed partially (in terms of access to open space) in Target 11.7, although the emphasis is on personal safety free from physical and sexual harassment: "By 2030, provide universal access to safe, inclusive and accessible, green and public spaces, in particular for women and children, older persons and persons with disabilities". Target 11.3 refers indirectly to integration of land use and transport as its indicator is weighted by "land consumption rate". Again, though, the lack of targeted measures is a cause for concern. Each member state is free to interpret these goals to their own national standards. There will, of course, be vast differences between the criteria that are considered important when discussing universal access in Thailand or in Norway. 
By their very nature, these goals are meant to be general enough to enable adoption and adaptation by member states and are meant for monitoring purposes. However, one could have hoped for more ambition and more alignment with state-of-the-art concerns in transport and mobility planning for such future-oriented goals. The danger here lies in the context-less and governance-free goals that are proposed. This presupposes an ability to progress from current levels, and assumes that there is an acceptable baseline from which to progress. In reality, transport and mobility planning are crucial sectors that require combined expertise from multiple sectors and disciplines, as seen from the cases of Singapore and Jakarta below.

\section{L2 Singapore}

Singapore is a dense and highly urbanized city with nearly 6 million inhabitants spread over about $722 \mathrm{~km}^{2}$. Within the island state, there is a polycentric settlement patterns of satellite towns in each cardinal direction functioning as stand-alone hubs for employment, commerce, education, and healthcare (Buijs et al., 2010). However, most commuter journeys are still oriented towards the existing and new central business districts (CBD and Downtown Core) in the south of the island. The biggest challenges facing Singapore are lack of land and increasing population growth; these have informing decades of policies to curb urban sprawl while preserving nature areas for drinkable water supply (Barter, 2008). This section examines two projects - the increase of walking and cycling comfort under the Walk2Ride scheme and the National Cycling Plan, and the improvement of integrated transport hubs — which form part of the Land Transport Master Plan 2013.

\section{$\underline{\text { L3 Walk2Ride and National Cycling Plan }}$}

The implementation agency, Land Transport Authority (LTA), has been steadily developing sheltered walkways within $200 \mathrm{~m}$ of all public transport nodes and connecting all nodes to educational or healthcare facilities to shelter users from the tropical climate. With the new Walk2Ride programme, the sheltered walkway network now also connects to more services such as "public amenities, offices and residential developments within $400 \mathrm{~m}$ of the stations; bus interchanges and LRT stations to developments within a 200m radius; selected bus stops with very high usage to trip-generating hubs within a 200m radius" (LTA, 2013a, pp. 24-25). The expansion of sheltered walkways is significant for the expected increase in the user group of the elderly and 
the less mobile, and appropriately offers more resting areas and signage at key points to guide pedestrians towards transit hubs. In addition, seven satellite towns (Tampines, Yishun, Pasir Ris, Sembawang, Taman Jurong, Changi-Simei and Bedok) identified as growth areas, as well as the new downtown area (Marina Bay), are being improved with dedicated cycling networks to connect these residential and commercial hubs, and better cycling facilities including a bike-sharing scheme under the National Cycling Plan (LTA, 2013a).

\section{L3 People-centred Land Transport System}

Singapore has adopted a comprehensive approach to transportation and land use planning since the 1970s (Lam \& Toan, 2006). There is also a strong formal tradition of masterplans for the long term (i.e. 20 years), reviewed every five years (Yuen, 2011). Since the 1991 Constellation Plan, the national government, acting through its ministries for transport and national development and their various statutory boards, has enacted a transit-oriented development strategy to concentrate satellite towns and developments along transit corridors as integrated transport hubs (Yang \& Leng, 2009). These hubs are part of the mass rapid transit network in Singapore developing from an east-west and north-south corridor to a fully fledged wheel-and-spoke-network with five lines and 117 stations, with more satellite towns covered by either heavy urban rail (MRT) or light rail (LRT). The network will be expanded in the coming years to include four more lines. The transit services and hubs are run by the SMRT Corporation Ltd., a multi-modal land transport provider that was initially privatized but was recently delisted and is now owned by the LTA. In the latest iteration of the Transport Masterplan with a clear set of targets and guidelines (LTA, 2013a), the following objectives related to sustainable mobility are found:

1) Improve bus and rail service efficiency through technical and information systems upgrading and expansion of rail network;

2) Increase safety and accessibility for elderly and the less mobile;

3) Reduce private vehicle reliance by restricting purchase and satellite-based road pricing system;

4) Facilitating more walking and cycling through network extensions, sheltered walkways or bike-sharing schemes.

These objectives and measures are an extension of the authorities' decades-long plans to discourage private vehicle use, encourage shared mobility and integrate land use and transport developments (Diao, 2018). There is also a traceable rise in the concern for social and individual aspects (safety, 
accessibility, and comfort) — an increasingly "people-centred" approach — since the 2008 Transport Masterplan (LTA, 2008).

\section{$\underline{\text { L3 Singapore: Legacy and Innovation }}$}

In terms of sustainable mobility, Singapore, with its direct governance structure (i.e. a national plan supported by parallel ministries and implemented in coordination) fulfils all four elements of sustainable mobility with its previous and current master plans (Diao, 2018; Yang \& Leng, 2009). Aside from efficiency increases for services through technology, there is a substantial effort to deter private vehicle ownership by making the real costs of car ownership explicit through the need to purchase a licence to own and through dynamic road pricing (Han, 2010). The current master plan also coordinates the walking and cycling strategy to increase active mobility as a first- and last-mile option for its users. There has been a large-scale effort to gain citizen feedback through surveys and panels (LTA, 2008, 2013b). Cycling has yet to be mainstreamed in Singapore but at least 22\% of all trips in 2011 were made using pedestrian modes (Palliyani \& Lee, 2017). There has been a steady increase in public transportation mode share from $65 \%$ in 2008 to $71 \%$ in 2012 for those within close proximity of transit hubs (LTA, 2013b). The case of Singapore demonstrates that SDG Target 11.2 could work if the basic networks and infrastructure quality levels are already present. The proportion of population with "convenient access" could indeed be increased (Indicator 11.2.1) through TOD policies in tandem with complementary walking and cycling programmes. The majority of trips taken by public transport involve those who live close to it, thereby signifying high acceptance. In addition, the sheltered walkway and cycling facilities in Singapore are meant to cater to a vulnerable population by providing access, comfort, and/or safety (Indicator 11.3.2).

\section{L2 Jakarta}

As the central node of the Jabodetabek metropolitan region, Jakarta city is the cultural, commercial, financial, and administrative centre and experiences large commuter flows from the surrounding eight cities (Hasibuan, Soemardi, Koestoer, \& Moersidik, 2014). As one of Southeast Asia's largest megacities, it has more than 10 million inhabitants spread over $662 \mathrm{~km}^{2}$. Within Jakarta city, the residential areas are on the outskirts (including the low-income housing developed in North Jakarta for relocated slum residents), while the employment and retail districts are in the middle (Feminin, Wiranegara, \& Supriatna, 2018). After decades of rapid urbanization and motorization of traffic, 
bringing negative health and societal impacts, there has been some interest from local government and communities in adopting more sustainable transportation models and networks.- This section focuses on the increase of cycling as an alternative mode of travel, backed by civil society, and the development of TOD areas on the city's north-south corridor.

\section{$\underline{\text { L3 Cycling Communities and Car-free Days }}$}

The first cycling lane was opened in 2011, between Ayodia Park and Blok M in South Jakarta, made possible by generous donations equivalent to US\$5,600 from the cycling community (Komite Sepeda Indonesia) (Rukmana, 2011). At the time of writing, the city boasts $26 \mathrm{~km}$ of dedicated but fragmented - cycling infrastructure and the provincial government claims that more will be added to connect other parts of the city as part of the TOD projects planned for the north-south corridor (Indonesia Expat, 2018). Apart from these infrastructural projects, cycling does not represent a priority for the local authorities. In fact, most of the resources and capacities comes from civil society, in the forms of cycling enthusiasts such as the citizen-led group, Bike2Work (Pearl, 2015). Active mobility is in its early days in Jakarta, despite the car-free days which have been held every Sunday for the past decade. The issue is not just public acceptance of cycling as an option, but the very real dangers of traffic where a majority of the users are in motorized vehicles and have little understanding of non-motorized traffic (㳕hanesta \& Bawono, 2017). In addition, walking is seen as challenging or dangerous due to the discontinued sidewalks, bad quality of the pavements and the use of pedestrian spaces for illegal or informal businesses (Zulkifli, Hino, Pattinaja, \& Tjahjani, 2009).

\section{$\underline{\text { L3 TOD on the North-South Corridor }}$}

Against a backdrop of democratization and decentralization of spatial planning for the metropolitan region (Rukmana, 2015), mass rapid transit was declared a national project in 2005 (although plans for it had existed since 1985). This activated the central government and the provincial government (DKI Jakarta) to start transit-oriented developments with loans provided by the Japanese government (MRT Jakarta, 2018a). Phase 1 of the $16 \mathrm{~km}$ north-south corridor started in 2013 and is currently under construction by PT MRT Jakarta - a private company owned mainly by DKI Jakarta that operates, constructs, and maintains urban rail infrastructure and facilities (ibid.). In 
addition, it develops and manages property and businesses around the stations. Plans for TOD were prompted by increasing pressures resulting from congestion caused by private vehicles, and the sprawling urban land use (MRT Jakarta, 2018b). Of the eight Phase 1 stations designated as TOD, PT MRT Jakarta is developing an integrated master plan for the stations Lebak Bulus, Fatmawati, Cipete area (with Cipete Station, Haji Nawi Station, Blok A Station), Blok M area (with Sisingamangaraja Station), and Dukuh Atas. Some of these station areas are being advertised to attract public-private investment partnerships (JIC, 2017). Eight principles guide the design of the station areas, namely the increase of mixed land use functions; high-density developments; quality of connections to different modes; quality of life in terms of safety; social equality for marginalized groups previously lacking accessibility; environmental sustainability; infrastructure resilience from disasters and climate change; and development of local economy and employment. In terms of sustainable mobility, PT MRT Jakarta's objectives for these areas are (MRT Jakarta, 2018b):

1) Reduce private vehicle use and corresponding road congestion and air pollution;

2) Support walking, and healthy and active lifestyle;

3) Increase access to employment and economic opportunities;

4) Increase transit passenger numbers and ticket sale profits;

5) Increase mode choice for the urban area.

\section{$\underline{\text { L3 Jakarta: Car-oriented Late Bloomer }}$}

In terms of sustainable mobility, Jakarta is hitting most of the four elements with its TOD policy objectives. From adoption of new technologies - heavy and light rail and electronic ticketing - to the integration of station area development with transport system improvements, the local and regional government are investing in behavioural change and acceptance. The true test will be in the implementation process and adoption by its citizens beyond the rhetoric.

However, ongoing fuel subsidies and the lethargic governance response to sustainable transportation are indications of the car-oriented socio-political environment in Jakarta (Stsilo et al., 2007). With regard to the city's non-existent cycling policies, the good news is that there is an active civil society that is engaged and willing to motivate authorities to take a leap. Although now considered only as a leisure pursuit, the mainstreaming of cycling could, with the help of car-free days, start to create a mindset change in the public. The case of Jakarta thus shows that SDG 11 is too general when it comes to implementation. Even if the percentage of population (as per Indicator 
11.2.1) could be increased through TOD policies, these individuals would still have to be able to walk or even cycle to those station locations. Given the large population, the rate of land consumption is already out of proportion (Indicator 11.3.1) and would be impossible to reverse without drastic de-urbanization. There are also other factors to consider, such as inhabitants who are currently disenfranchised in informal settlements and those who have been relocated to lowerincome housing areas, being even further disadvantaged in terms of access to employment and services (Feminin et al., 2018).

\section{L1 Comparing Singapore and Jakarta}

Singapore and Jakarta might be incomparable in many respects; however, to give an impression of the transportation choices available to inhabitants, it is possible to compare the distance, time, and cost required for an individual to journey from her/his home in a commuter suburb to the central business districts of each city. This comparison is intended to give an insight into the issues relevant for sustainable mobility and eventual implementation of the SDGs. Taking a closer look at both cities, the northern suburb of Woodlands is identified for Singapore and North Jakarta for Jakarta. Both suburbs are located $17 \mathrm{~km}$ north of the central commercial area of their respective cities.

Fate 1 shows that comparing a similar trip from the commuter town to the city centre $17 \mathrm{~km}$ away, in Singapore and Jakarta, yields the following results:

i) Distance: distances by car and on foot are similar for the two cities. However, for Jakarta, there are arice as many transfers needed to complete the journey by public transportation and a significant increase (of 300\%) in walking distance for a door-to-door trip by public transportation.

ii) Time: the car journey in Jakarta takes almost twice as long as in Singapore, while public transport (rail) requires 144\% more time than in Singapore and public transport (bus) requires $46 \%$ more time. For walking, the journey in Singapore will take $20 \%$ more time than in Jakarta.

iii) Cost: all modes are significantly more expensive in Singapore than in Jakarta, although in Singapore, public transport rates are differentiated depending on the user group (e.g. elderly or students).

Taking the above comparison at face value, it seems that it takes more time in Jakarta to complete our hypothetical journey, but it is significantly less expensive than a similar journey in Singapore. 
However, if we factor in the difference in average net monthly salary between Singapore (US\$2,891) and Jakarta (US\$350) (Numbeo, 2018), an inhabitant in Jakarta actually spends 4.4\% of their daily net income to commute back and forth to work, while an inhabitant in Singapore spends only $2.8 \%$ (or $3.7 \%$ without discounts). This is a significant difference, especially considering that the Jakarta journey also takes more time and offers much less comfort (more transfers and greater walking distances). With a low to median income, our Jakarta traveller sacrifices not only a portion of their income but also time which could theoretically be used for earning income to get to and from work. This comparative exercise thus throws into sharp relief the issues of social and economic inequality as presented through mobility choices.

There are a number of contextual limitations and qualifiers to take into account. The reader should bear in mind that the two cities differ vastly in terms of economic welfare and governance structures. In addition, the cost of owning a car in Singapore is prohibitive, estimated at SG\$18,000 (approximately US\$13,000) per year (Wong, 2017). Acquiring ownership entails a process of bidding for certificates of entitlement (COEs), which are limited and regulated by the authorities: private vehicle ownership is therefore only available to a small elite. These indirect taxes make it possible for the Singapore government to subsidize the costs of public transport. In direct contrast, the cost of car ownership is much lower in Jakarta, fuel is subsidized, and there is an accessible domestic market for private vehicles.

\section{L2 Policies and Acceptance}

Both cities have some form of active mobility project and LUTI policy. The key differences are found in (1) how long these policies and projects have been adopted as part of a long-term strategy or plan, and (2) the stakeholders involved in decision making and implementation.

In Singapore, the comprehensive land use and transport master plan is the current iteration of a set of policies and strategies going back to the late 1960s. Singapore has had decades to refine and improve upon those plans and has consistently done so with sustainable transportation and mobility in mind (Diao, 2018; Yang \& Leng, 2009; Yuen, 2011). The latest master plan shows not only network expansion (for rail and bus) but also investments to improve rider comfort and the quality of the pedestrian network. The plans encompass more than just transportation system improvement but also look at safety and inclusion of vulnerable groups. There is a linear and hierarchical governance structure - a single authority coordinating across multiple ministries and agencies but implementing on one level — which makes implementation appear effortless. SMRT, as the 
transport provider and at times developer, has a direct line to the ministries and implementing agency of LTA (LTA, 2018a, 2018b). However, what seems to be missing in the Singapore case is the voice and actions of civil society and non-governmental actors.

In Jakarta, the slow adoption of sustainable mobility policies in the form of transit-oriented development has been attributed to lack of political will and urgency, and pushback from caroriented citizens unfamiliar with these types of policies (Susilo et al., 2007). The mass rapid transit (urban rail) development was expected to benefit the socio-economically marginalized groups, particularly women who were previously subject to safety and harassment issues. However, the new commuter lines have achieved limited success in this regard, as low-income residents in North Jakarta who have been relocated from slums are dissatisfied with their level of accessibility (Feminin et al., 2018). The most crucial barrier to sustainable mobility in Jakarta is not the lack of policies but rather the lack of policies that target the most basic network - sidewalks and pavements - required to provide access to all by increasing safety from motorized traffic, and connectivity for pedestrians. Compared with Singapore, there is also a much greater variety of stakeholders involved in Jakarta. Here, foreign governments play a significant role supporting the TOD plans financially and in knowledge transfer (Turner, 2011), while the cycling network is mostly promoted and funded by civil society.

\section{L1 Discussions}

Returning to the discussion of SDG 11, it becomes clear that the indicators related to transport are, on their own, insufficient to achieve sustainable cities and communities. Diving into the intricacies of mobility and transport planning, as witnessed by the cases of Singapore and Jakarta, shows that there are many more factors to consider in order to achieve sustainable transportation or development. The comparison of the fictitious journeys showcases the need to consider social, economic, and political contexts. Factors such as political will, governance structures, and public acceptance also play an important role. Singapore has been able to implement sustainable mobility due to a consistent strategy and streamlined governance structure. The differences between conventional transport planning and sustainable mobility can offer insights here, as they show that cross-sectoral coordination is required to move away from the "predict and provide" narrative to consider the socio-economic and cultural outcomes and impacts of mobility policies. The land use and transportation masterplan in Singapore shows that it is not sufficient to just consider quantities (i.e. proportion of population with access to public transportation); rather, we need to look at the 
potential for accessing those hubs, under what conditions access is granted (comfort, safety, or time and cost in relation to income levels), and to whom. Sustainable cities and communities are closer to being achieved when the marginalized and vulnerable are considered and prioritized in policies and implementation. Likewise, when civil society stakeholders are active, as in Jakarta, democratic rule and governance benefit even where policy capacity and implementation are lacking.

Making cities and human settlements inclusive, safe, resilient, and sustainable is an ambitious goal. It will require a change in the status quo and innovative measures. Innovations in mobility planning are made possible through coordinated change in governance and cultural shifts in transportation behaviour (Homrighausen \& Tan, 2016). Political will and public acceptance can contribute significantly to a shift from a business-as-usual approach to a sustainable mobility approach when it comes to the transportation system. There is a role here for the government, private parties, and civil society. The case of Singapore depicts the efficiency of a stable government with consistent policy goals, and demonstrates the need for a transparent governance structure that allows for community feedback and participation as shown in the latest master plans. The case of Jakarta highlights the potential for private investment opportunities with the realization of TOD projects and corresponding urban development. Both cases show that civil society has a role to play in reducing mobility inequalities, either by reflecting current imbalances (e.g. Singapore's masterplan feedback panels) or by stepping up and navigating policy change when political will is lacking (e.g. Jakarta's cycling community). The efficacy of SDG 11 could be improved if it were to move beyond a pure measuring instrument to affect and sustain systemic change by adopting the sustainable mobility approach to address mobility inequalities and social exclusion.

\section{L1 References}

Annema, J. A. (2013). Transport resistance factors: Time, money and effort. In D. Banister, B. P. van Wee, \& J. A. Annema (Eds), The Transport System and Transport Policy (pp. 101-121). Cheltenham: Edward Elgar Publishing.

Bakker, S., Contreras, K. D., Kappiantari, H., Tuan, N. A., Guillen, M. D., Gunthawong, G., ... van Maarseveen, M. (2017) Low-carbon transport policy in four ASEAN countries: Developments in Indonesia, the Philippines, Thailand and Vietnam. Sustainability, 9(7), 1217.

Banister, D. (2008). The sustainable mobility paradigm. Transport Policy, 15(2), 73-80. 
Banister, D. (2011). Cities, mobility and climate change. Journal of Transport Geography, 19(6), $1538-1546$.

Barter, P. (2004) Transport, urban structure and 'lock-in' in the Kuala Lumpur Metropolitan Area. International Development Planning Review, 26(1), 1-24.

Barter, P. A. (2008). Singapore's urban transport: Sustainability by design or necessity? In T. C. Wong (Ed.), Spatial planning for a sustainable Singapore (pp. 95-112). Dordrecht: Springer Netherlands.

Buijs, S., Tan, W. G. Z., \& Tunas, D. (2010) Governance of megacities. In W. G. Z. Tan et al. (Eds), Megacities (pp. 275-285). Rotterdam: 010 Publishers.

Clark, C. (1958) Transport: Maker and breaker of cities. The Town Planning Review, 28(4), 237. Coggin, T. (2017). A right to transport? Moving towards a rights-based approach to mobility in the city. South African Journal on Human Rights, 31(2), 294-314.

Development Initiatives (2017). Financing the Sustainable Development Goals in ASEAN: Strengthening integrated national financing frameworks to deliver the 2030 Agenda. Report commissioned by UNDP's Regional Bureau for Asia and the Pacific. Retrieved from http://asean.org/storage/2012/05/Report-on-Financing-SDGs-in-ASEAN1.pdf

Diao, M. (2018). Towards sustainable urban transport in Singapore: Policy instruments and mobility trends. Transport Policy [online].

Feminin, T. A., Wiranegara, H. W., \& Supriatna, Y. (2018). Accessibility of low-income family flats in North Jakarta city. IOP Conference Series: Earth and Environmental Science, $106,012030$.

Firman, T., \& Dharmapatni, I. A. I. (1994). The challenges to sustainable development in Jakarta metropolitan region. Habitat International, 18(3), 79-94.

Han, S. S. (2010). Managing motorization in sustainable transport planning: The Singapore experience. Journal of Transport Geography, 18(2), 314-321.

Hasibuan, H. S., Soemardi, T. P., Koestoer, R., \& Moersidik, S. (2014). The role of transit oriented development in constructing urban environment sustainability: The case of Jabodetabek, Indonesia. Procedia Environmental Sciences, 20, 622-631.

Homrighausen, J. R. \& Tan, W. G. Z. (2016) Institutional innovations for sustainable mobility: Comparing Groningen (NL) and Phoenix (US). Transportation Research Procedia, 19.151-163.

Hull, A. (2008). Policy integration: What will it take to achieve more sustainable transport solutions in cities? Transport Policy, 15(2), 94-103. 
Indonesia Expat (2018). Jakarta plans to build more bicycle lanes. Indonesia Expat. Retrieved from http://indonesiaexpat.biz/news/jakarta-plans-build-bicycle-lanes/ (last accessed 3 June 2018).

IAEG (2016). Global indicator framework. Report of the Inter-Agency and Expert Group on Sustainable Development Goal Indicators (E/CN.3/2016/2/Rev.1), Annex IV. Geneva: UN Inter-Agency and Expert Group.

INRIX (2017). Interactive ranking \& city dashboards: Hours spent in congestion. Retrieved from http://inrix.com/scorecard/ (last accessed 3 June 2018).

JIC (2017). Jakarta investment project digest 2017-2018. Jakarta: Jakarta Investment Centre. Retrieved from https://www.bkpm.go.id/images/uploads/berita_acara_iipc_fileupload/Jakarta_Investm ent_Project_Digest.pdf

Johnson, C. (1999). The developmental state: Odyssey of a concept. In M. Woo-Cummings (Ed.), The developmental state (pp. 32-92). Ithaca, NY: Cornell University Press.

Kenworthy, J. (2007). Urban planning and transport paradigm shifts for cities of the post-petroleum age. Journal of Urban Technology, 14(2), 47-70.

Kenyon, S., Lyons, G., \& Rafferty, J. (2002). Transport and social exclusion: Investigating the possibility of promoting inclusion through virtual mobility. Journal of Transport Geography, 10(3), 207-219.

Ladd, B. (2012). 'You can't build your way out of congestion' — Or can you? disP - the Planning Review, 48(3), 16-23.

Lam, S. H., \& Toan, T. D. (2006). Land transport policy and public transport in Singapore. Transportation, 33(2), 171-188.

LTA (2008). What transport must do: Connect newsletter April 2008. Land Transport Authority. Retrieved from https://www.lta.gov.sg/content/dam/ltaweb/corp/PublicationsResearch/files/ReportNe wsletter/Connect/Connect_April_FA.pdf (last accessed 3 June 2018).

LTA (2013a). Land transport master plan 2013. Singapore: Land Transport Authority. Retrieved from https://www.lta.gov.sg/content/dam/ltaweb/corp/PublicationsResearch/files/ReportNe wsletter/LTMP2013Report.pdf (last accessed 3 June 2018).

LTA (2013b). Household interview travel survey 2012: Public transport mode share rises to 63\%. Singapore: Land Transport Authority. Retrieved from 
https://www.lta.gov.sg/apps/news/page.aspx?c=2\&id=1b6b1e1e-f727-43bb-8688-

f589056ad1c4 (last accessed 3 June 2018).

Loo, B. P. Y., \& du Verle, F. (2016). Transit-oriented development in future cities: Towards a twolevel sustainable mobility strategy. International Journal of Urban Sciences, 21(Sup1), $54-67$.

Lucas, K. (2012). Transport and social exclusion: Where are we now? Transport Policy, 20, 105113.

Lucas, K., van Wee, B. P., \& Maat, K. (2016). A method to evaluate equitable accessibility:

Combining ethical theories and accessibility-based approaches. Transportation, 43(3), 473-490.

Mees, P. (2014). TOD and multi-modal public transport. Planning Practice and Research, 29(5), 461-470.

MRT Jakarta (2018a). Sejarah. MRT Jakarta. Retrieved from https://www.jakartamrt.co.id/mrtjakarta/sejarah-mrt-jakarta/ (last accessed 3 June 2018).

MRT Jakarta (2018b). Kawasan Berorientasi Transit (TOD). MRT Jakarta. Retrieved from https://www.jakartamrt.co.id/konektivitas/transit-oriented-development-tod/ (last accessed 3 June 2018).

Numbeo (2018) Cost of living comparison between Jakarta and Singapore. Retrieved from https://www.numbeo.com/cost-of-

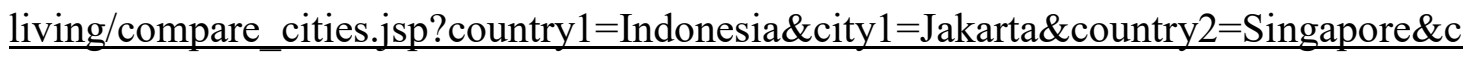
ity $2=$ Singapore \&displayCurrency=USD (last accessed 3 June 2018).

Owens, S. (1995). From 'predict and provide' to 'predict and prevent'? Pricing and planning in transport policy, Transport Policy, 2(1), 43-49.

Pzilliyani, S. \& Lee, D.H. (2017). Sustainable transport policy: An evaluation of Singapore's past, present and future. Journal of Infrastructure, Policy and Development, 1(1), 112-17.

Pearl, H. (2015). Cycling the city: 'I have a dream that Jakarta should be like Copenhagen'.

Retrieved from http://www.theguardian.com/cities/2015/sep/10/cycling-jakarta-dreamcopenhagen-indonesia-bike (last accessed 3 June 2018).

Preston, J., \& Rajé, F. (2007). Accessibility, mobility and transport-related social exclusion. Journal of Transport Geography, 15(3), 151-160.

Pucher, J., \& Dijkstra, L. (2011). Promoting Safe Walking and Cycling to Improve Public Health: Lessons From The Netherlands and Germany. American Journal of Public Health, 93(9), 1509-1516. 
Rama, M., Béteille, T., Li, Y., Mitra, P. K., \& Newman, J. L. (2015). Addressing inequality in South Asia. Washington, DC: World Bank Group.

Rukmana, D. (2011). Indonesia's biggest city gets its first bicycle lane. Retrieved from http://thisbigcity.net/indonesias-biggest-city-gets-its-first-bicycle-lane/ (last accessed 3 June 2018).

Rukmana, D. (2015). The change and transformation of Indonesian spatial planning after Suharto's New Order Regime: The case of the Jakarta Metropolitan Area. International Planning Studies, 20(4), 350-370.

SBS Transit (2018). Transit fares overview. Retrieved from https://www.sbstransit.com.sg/transport/trpt fares_overview.aspx [(last accessed 3 June 2018).

Scheurer, J., Curtis, C., \& McLeod, S. (2017). Spatial accessibility of public transport in Australian cities. Journal of Transport and Land Use, 10(1), 911-930.

Shatkin, G., (2008), The city and the bottom line: Urban megaprojects and the privatization of planning in Southeast Asia. Environment and Planning A, 40(2), 383-401.

Susilo, Y. O., Joewono, T. B., Santosa, W., \& Parikesit, D. (2007). A Reflection of Motorization and Public Transport in Jakarta Metropolitan Area: Lessons Learned and Future Implications Towards Better Transportation Development in Developing Countries. Proceedings of the Eastern Asia Society for Transportation Studies, 6, 46-46.

Tan, W. G. Z., Bertolini, L., \& Janssen-Jansen, L. B. (2014). Identifying and conceptualising context-specific barriers to transit-oriented development strategies: The case of the Netherlands. Town Planning Review, 85, 639-663.

Thynell, M. (2017), Roads to equal access: The role of transport in transforming mobility. Transport and Communications Bulletin for Asia and the Pacific, 87, 77-87.

TomTom (2017) TomTom traffic index: Measuring congestion worldwide. Retrieved from https://www.tomtom.com/en_gb/trafficindex/list?citySize=LARGE\&continent=ALL\& country=ALL (last accessed 3 June 2018).

Turner, J. (2011). Urban mass transit and social sustainability in Jakarta, Indonesia. Nairobi: UN Habitat.

UN (1948) Universal Declaration of Human Rights. New York: United Nations General Assembly. Retrieved from http://www.un.org/en/universal-declaration-human-rights/. (last accessed 3 June 2018).

UN (2015). Transforming our world: The 2030 Agenda for Sustainable Development. New York: United Nations. Retrieved from undocs.org/A/RES/70/1 (last accessed 3 June 2018). 
UN (2017). Work of the statistical commission pertaining to the 2030 Agenda for Sustainable Development (A/RES/71/313), Annex (6 July 2017). New York: United Nations. Retrieved from undocs.org/A/RES/71/313 (last accessed 3 June 2018).

UN ESCAP (2017). Complementarities between the ASEAN Community Vision 2025 and the United Nations 2030 Agenda for Sustainable Development. Bangkok: United Nations. Retrieved from https://www.unescap.org/publications/complementarities-betweenasean-vision-2025-and-2030-agenda (last accessed 3 June 2018).

UN HABITAT (2013), Planning and Design for Sustainable Urban Mobility: Global Report on Human Settlements. New York: Routledge.

Wegener, M., \& Fürst, F. (1999). Land-use transport interaction: State of the art. TRANSLAND. Dortmund: European Commission.

Wihanesta, R., \& Titis Bawono, E. (2017, September 12). Jokowi's bike: Where are the lanes? Retrieved from http://www.thejakartapost.com/academia/2017/09/12/jokowis-bikewhere-are-the-lanes.html (last accessed 3 June 2018).

Wilson, R. (2001). Assessing communicative rationality as a transportation planning paradigm. Transportation, 28(1), 1-31.

Wong, J. (2017). How much it really costs to own a car in Singapore. Channels News Asia.

Retrieved from https://www.channelnewsasia.com/news/brandstudio/how-much-itreally-costs-to-own-a-car-in-singapore-9346730 (last accessed 3 June 2018).

World Bank (2015). East Asia's changing urban landscape. Washington, DC: World Bank. Yang, P., \& Leng, S. H. (2009). An Asian model of TOD: The planning integration in Singapore. In L. Bertolini, J. L. Renne, \& C. Curtis (Eds), Transit-oriented development: Making it happen (pp. 91-108). New York: Taylor \& Francis.

Yuen, B. (2011). Urban planning in Southeast Asia. Centenary paper: Urban planning in Southeast Asia: perspective from Singapore. The Town Planning Review, 82(2), 145-167.

Zulkifli, M., Hino, Y., Pattinaja, A., \& Tjahjani, I. (2009). Limitation of walking facilities in Jakarta: A visual analysis on actual condition and user's perception. Proceedings of the Eastern Asia Society for Transportation Studies, 7, 260-272. 